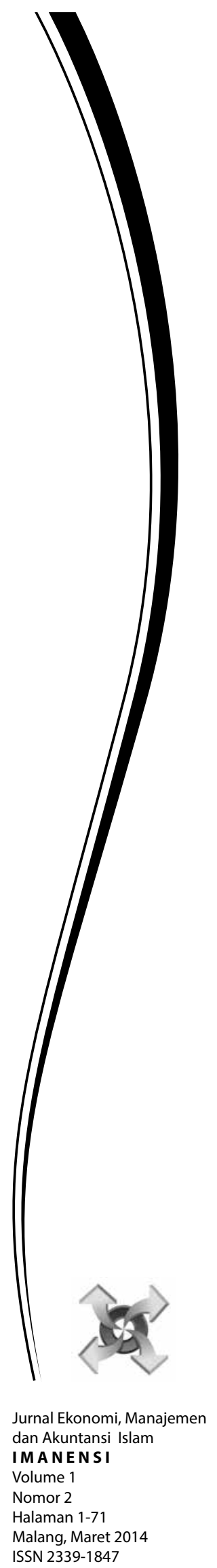

\title{
ANALISIS ALTERNATIF PEMBIAYAAN TAKE OVER BERDASARKAN PRINSIP SYARIAH (HAWALAH)
}

\author{
Achmad Zaky \\ Universitas Brawijaya, Jl. MT. Haryono 165, Malang \\ Surel: Keuangansyariah@gmail.com
}

\begin{abstract}
Abstrak. Analisis Alternatif Pembiayaan Take Over Berdasarkan Prinsip Syariah (Hawalah). Penelitian ini bertujuan untuk menjelaskan kesesuaian karakteristik akad dan prinsip syariah, serta implikasi perlakuan akuntansi masingmasing alternatif yang ditawarkan oleh Fatwa DSN MUI Nomor: 31/DSN-MUI/ VI/2002 tentang pengalihan hutang. Penelitian ini menggunakan pendekatan kualitatif dengan metode studi kepustakaan (library research), dimana data-data diperoleh dari buku, jurnal, maupun catatan penelitian terdahulu. Hasil penelitian menunjukkan bahwa masing-masing alternatif yang merupakan rangkaian akad qardh, ijarah, murabahah, syirkah al milk dan ijarah muntahiyah bit at tamlik menghadapi kendala pada ketidaksesuaian dengan prinsip dan karakteristik transaksi syariah, meskipun telah difatwakan oleh DSN MUI. Selain itu, masingmasing alternatif yang ditawarkan memiliki implikasi perlakuan akuntansi yang relatif kompleks.
\end{abstract}

Abstract. Alternative Analysis of Take Over Financing According Sharia Principle (Hawalah). This research aims to explain the suitability of contract characteristics and sharia principle, as well as the accounting treatment implications of each alternative were offered by DSN MUI guidance No: 31/DSN-MUI/ VI/2002 about transfer of debt. This research uses qualitative approach with literature study (library research) method, which datas are get from books, journals, and previous research notes. The result indicates that each alternative is a series of qardh, ijarah, murabahah, ijarah shirkah al milk and ijarah muntahiyah bits at tamlik have constraint on uncompliance with the principle and characteristics of sharia transactions, although has been instructed by DSN MUI. Additionally, each of the alternatives which offered have a relatively complex of accounting treatment implication.

Kata kunci: Hiwalah, Qardh, Ijarah, Murabahah, Syirkah al Milk, Ijarah Muntahiyah bit at Tamlik

Upaya pengembangan perbankan syariah di Indonesia mendapat dukungan yang besar dari pemerintah melalui Bank Indonesia (BI). Upaya tersebut telah dimulai dari tahun 2002 melalui "Cetak Biru Pengembangan Perbankan Syariah di Indonesia" (Bank Indonesia 2011a) dan Grand Strategi Pengembangan Pasar Perbankan Syariah (Bank Indonesia 2011c).

Upaya yang dilakukan setidaknya saat ini tengah membuahkan hasil yang cukup menggembirakan, setidaknya tampak pada pertumbuhan aset perbankan syariah satu dekade terakhir, total aset perbankan syariah telah tumbuh dari 3,58 Trilyun pada menjadi 79,64 Trilyun pada Agustus 2010 (Bank Indonesia 2011b). Data pada Bank Indonesia (2013) menunjukkan bahwa Bank Umum Syariah (BUS) telah tumbuh dari 3 unit pada tahun 2005 menjadi 11 pada tahun 2013. Semenjak diberlakukan UU No 21 Tahun 2008, pertumbuhan industri perbankan syariah telah mencapai rata-rata 65\% (Bank Indonesia 2011c). Upaya pengembangan ini diharapkan juga menyentuh pencapaian pangsa pasar perbankan 
syariah yang signifikan melalui pendalaman peran perbankan syariah dalam aktivitas keuangan nasional, regional dan internasional, dalam kondisi mulai terbentuknya integrasi dengan sektor keuangan syariah lainnya (Bank Indonesia 2011a).

Terlepas dari dukungan pihak regulator, kesadaran masyarakat akan kebutuhan perbankan yang memenuhi prinsip syariah juga terus tumbuh. Hal ini dibuktikan dengan pertumbuhan pembiayaan dan industri perbankan syariah. Bank Indonesia (2011c) juga telah mengidentifikasi bahwa salah satu motivasi masyarakat memilih bank syariah adalah pertimbangan dorongan kesadaran memenuhi prinsip syariah.

Meningkatnya kesadaran masyarakat untuk menjauhi transaksi ribawi (berbasis bunga) menjadikan tantangan tersendiri bagi pihak perbankan syariah. Peluang perpindahan nasabah yang terlanjur memanfaatkan pembiayaan berbasis bunga dari bank konvensional menuju pembiayaan yang memenuhi prinsip syariah juga terbuka lebar. Hal ini dibuktikan dengan desakan untuk dimunculkannya fatwa DSN yang memberikan alternatif pola pembiayaan pengambil-alihan utang (take over) dari bank konvensional menuju bank syariah.

Kebutuhan masyarakat dan praktisi terjawab dengan lahirnya Fatwa DSN MUI Nomor: 31/DSN-MUI/VI/2002 tentang pengalihan hutang. Dimana kemunculan fatwa ini memberikan alternatif pola pembiayaan pengambil-alihan utang yang dapat diterapkan pada produk perbankan syariah. MUI (2002) memberikan alternatif proses pengalihan utang dengan model hybrid contract. Mingka (2013b) menjelaskan bahwa hybrid contract merupakan kesepakatan dua pihak untuk melaksanakan suatu akad yang mengandung dua akad atau lebih terhimpun dalam satu kesatuan, serta semua hak dan kewajiban yang ditimbulkannya dipandang sebagai satu kesatuan yang tidak dapat dipisah-pisahkan, sebagaimana akibat hukum dari satu akad.

Lebih lanjut, Mingka (2013b) menilai hybrid contract pada tataran praktis di perbankan syariah Indonesia masih menimbulkan perdebatan akibat dari perbedaan pemahaman terkait boleh tidaknya melakukan penggabungan akad. Penjelasan Tarmizi (2012) yang mendasarkan pada larangan Nabi Muhammad SAW dan AAOIFI terkait penggabungan akad utang-piutang (qardh) dengan jual beli, mendorong pemikiran kri- tis terhadap solusi yang ditawarkan oleh MUI dalam Fatwa DSN No 31/2002 tersebut. Hayati (2008) juga memberikan penekanan untuk mengkaji secara mendalam solusi alternatif yang ditawarkan MUI tersebut agar tidak menjadikan masyarakat yang sudah berupaya meninggalkan transaksi ribawi menjadi terjebak kembali dalam transaksi ribawi.

Berdasarkan alternatif yang ditawarkan dalam fatwa DSN MUI No. 31 Tahun 2002 tersebut, setidaknya terdapat penggabungan akad dalam setiap alternatifnya, antara lain: (a) Alternatif 1 memberikan alternatif gabungan akad qardh dengan Murabahah. (b) Alternatif 2 memberikan alternatif gabungan akad Syirkah al milk dengan Murabahah. (c) Alternatif 3 memberikan alternative gabungan akad qardh dengan Ijarah. (d) Alternatif 4 memberikan alternative gabungan akad qardh dengan Ijarah muntahiyah bit tamlik.

Berdasarkan alternatif yang ditawarkan tersebut memunculkan keraguan sebagian kalangan terhadap kesesuaian dengan prinsip syariah dalam transaksi. Selain itu, pola pembiayaan yang ditawarkan akan menimbulkan dampak pada pola perlakuan akuntansi yang diterapkan. Terlebih lagi pengambil-alihan ini terjadi setelah proses perpindahan hak kepemilikan, namun harus melalui solusi pengambil-alihan yang berdampak adanya proses perpindahan kepemilikan lagi. Tidak dapat dipungkiri pola transaksi ini juga akan menimbulkan kerumitan tersendiri dalam perlakuan akuntansi yang diterapkan.

Mendasarkan pada kondisi inilah, mendorong peneliti untuk melakukan analisis terhadap setiap alternatif solusi model pembiayaan yang ditawarkan dalam Fatwa DSN MUI No. 31 Tahun 2002. Peneliti tertarik untuk mengkaji berdasarkan aspek kesesuaian terhadap prinsip syariah serta dampak terhadap perlakuan akuntansi yang ditimbulkannya.

Berdasarkan uraian latar belakang di atas, maka penelitian ini akan diarahkan untuk menjawab pertanyaan riset berikut: Apakah alternatif pembiayaan take over (hawalah) yang ditawarkan oleh DSN MUI telah sesuai dengan karakteristik akad dan transaksi yang sesuai dengan prinsip syariah?

Penelitian ini bertujuan untuk menjelaskan secara mendalam kesesuaian karakteristik akad dan prinsip syariah masing-masing alternatif yang ditawarkan oleh Fatwa DSN MUI Nomor: 31/DSN-MUI/ 
VI/2002 tentang pengalihan hutang. Penelitian ini difokuskan pada Fatwa DSN MUI Nomor: 31/DSN-MUI/VI/2002 tentang pengalihan hutang, untuk dikaji secara mendalam terkait kesesuaian karakteristik akad dan prinsip syariah masing-masing alternatif yang ditawarkan. Sehingga, penelitian ini tidak mendasarkan pada implementasi fatwa tersebut dalam operasional Lembaga Keuangan Syariah (LKS).

Penelitian ini diharapkan memberikan kontribusi teoritis berupa kajian akademik terhadap alternatif solusi pembiayaan take over pada LKS yang mendasarkan pada Fatwa DSN MUI Nomor: 31/DSN-MUI/VI/2002 tentang pengalihan hutang. Hasil dari penelitian ini diharapkan dapat menjadi masukan bagi regulator, dalam hal ini adalah DSN MUI agar lebih berhati-hati dalam mempertimbangkan penawaran alternatif model pembiayaan. Bagi praktisi LKS, diharapkan penelitian ini dapat memberikan masukan agar lebih mengedepankan prinsip kehatihatian dan substansi mengungguli bentuk (substance over form) dalam memenuhi prinsip syariah, sehingga tidak bersikap terlalu oportunis.

Karim (2005) menyatakan bahwa pembiayaan take over merupakan suatu bentuk pengalihan utang dari lembaga keuangan konvensional ke lembaga keuangan syariah. Dalam hal ini pihak bank syariah memberikan pembiayaan kepada nasabah guna melunasi kewajiban pada bank konvensional tersebut. Setelah pelunasan terjadi maka kewajiban nasabah beralih dari bank konvensional menuju bank syariah.

Pola pembiayaan seperti ini sejalan dengan konsep pengalihan utang dengan menggunakan prinsip syariah atau biasa disebut dengan akad hawalah. MUI (2000), Nurhayati dan Wasilah (2013) mendefinisikan akad hawalah sebagai akad pengalihan utang dari pihak yang berutang kepada pihak yang wajib membayar utang tersebut. Sifat dari akad hawalah ini pada dasarnya bagian akad tabarru' (sosial). Namun demikian, didalam aplikasi lembaga keuangan syariah, akad hawalah tidak dapat berdiri sendiri melainkan diwujudkan dalam kombinasi akad (hybrid contract).

MUI (2002) telah memberikan gambaran alternatif pola pembiayaan take over oleh lembaga keuangan syariah dari lembaga keuangan konvensional. Alternatif ini dituangkan dalam Fatwa DSN MUI Nomor: 31/DSN-MUI/VI/2002 tentang pengalihan hutang. Dimana dalam fatwa tersebut ditawarkan beberapa alternatif sebagai berikut:

\section{ALTERNATIF I}

1. LKS memberikan qardh kepada nasabah. Dengan qardh tersebut nasabah melunasi kredit (utang)-nya; dan dengan demikian, asset yang dibeli dengan kredit tersebut menjadi milik nasabah secara penuh.

2. Nasabah menjual aset dimaksud angka 1 kepada LKS, dan dengan hasil penjualan itu nasabah melunasi qardh-nya kepada LKS.

3. LKS menjual secara Murabahah aset yang telah menjadi miliknya tersebut kepada nasabah, dengan pembayaran secara cicilan.

4. Fatwa DSN Nomor: 19/DSN-MUI/ IV/2001 tentang al-Qardh dan Fatwa DSN Nomor: 04/DSN-MUI/IV/2000 tentang Murabahah berlaku pula dalam pelaksanaan Pembiayaan Pengalihan Utang sebagaimana dimaksud alternatif I ini.

\section{ALTERNATIF II}

1. LKS membeli sebagian aset nasabah, dengan seizin LKK; sehingga dengan demikian, terjadilah Syirkah al-milk antara LKS dan nasabah terhadap aset tersebut.

2. Bagian aset yang dibeli oleh LKS sebagaimana dimaksud angka 1 adalah bagian aset yang senilai dengan utang (sisa cicilan) nasabah kepada LKK.

3. LKS menjual secara Murabahah bagian aset yang menjadi miliknya tersebut kepada nasabah, dengan pembayaran secara cicilan.

4. Fatwa DSN Nomor: 04/DSN-MUI/ IV/2000 tentang Murabahah berlaku pula dalam pelaksanaan Pembiayaan Pengalihan Utang sebagaimana dimaksud dalam alternatif II ini.

\section{ALTERNATIF III}

1. Dalam pengurusan untuk memperoleh kepemilikan penuh atas aset, nasabah dapat melakukan akad Ijarah dengan LKS, sesuai dengan Fatwa DSN-MUI Nomor: 09/DSN-MUI/IV/2002.

2. Apabila diperlukan, LKS dapat membantu menalangi kewajiban nasabah dengan menggunakan prinsip al-Qardh sesuai 
Fatwa DSN-MUI Nomor: 19/DSN-MUI/ IV/2001.

3. Akad Ijarah sebagaimana dimaksudkan angka 1 tidak boleh dipersyaratkan dengan (harus terpisah dari) pemberian talangan sebagaimana dimaksudkan angka 2.

4. Besar imbalan jasa Ijarah sebagaimana dimaksudkan angka 1 tidak boleh didasarkan pada jumlah talangan yang diberikan LKS kepada nasabah sebagaimana dimaksudkan angka 2 .

\section{ALTERNATIF IV}

1. LKS memberikan qardh kepada nasabah. Dengan qardh tersebut nasabah melunasi kredit (utang)-nya; dan dengan demikian, aset yang dibeli dengan kredit tersebut menjadi milik nasabah secara penuh.

2. Nasabah menjual aset dimaksud angka 1 kepada LKS, dan dengan hasil penjualan itu nasabah melunasi qardh-nya kepada LKS.

3. LKS menyewakan aset yang telah menjadi miliknya tersebut kepada nasabah, dengan akad al-Ijarah al-Muntahiyah bi al-Tamlik.

4. Fatwa DSN Nomor: 19/DSN-MUI/ IV/2001 tentang al-Qardh dan Fatwa DSN Nomor: 27/DSN-MUI/III/2002 tentang al-Ijarah al-Muntahiyah bi al-Tamlik berlaku pula dalam pelaksanaan Pembiayaan Pengalihan Utang sebagaimana dimaksud dalam alternatif IV ini. (MUI, 2002)

Nurhayati dan Wasilah (2013) mendefinisikan akad qardh sebagai akad pinjam meminjam dana tanpa ada persyaratan tambahan apapun. Lebih lanjut MUI (2001) lebih menekankan aspek teknis implementasi di lembaga keuangan syariah, sehingga qardh merupakan bentuk pinjaman lembaga keuangan syariah kepada nasabah, dimana nasabah wajib mengembalikan sejumlah yang terutang.

Dengan demikian, implementai akad qardh pada dasarnya merupakan utang piutang yang diberikan pihak lembaga keuangan syariah tanpa mensyaratkan tambahan apapun. Dengan demikian akad qardh merupakan akad sosial yang tidak ditujukan mencari keuntungan. Jika akad qardh berdiri sendiri maka hal ini memberikan sedikit perbedaan dengan sifat operasional perbankan syariah yang cenderung profit oriented. Oleh karena itu, akad qardh umumnya dimplementasikan dengan digabungkan dengan akad-akad komersial lainnya. Hal ini terbukti dengan statistik pembiayaan dengan akad qardh pada tahun 2013 berada pada posisi 3 besar (Bank Indonesia 2013).

IAI (2009) melalui Standar Akuntansi Keuangan Syariah telah memberikan ruang pada akad qardh sebagai bagian dari akad bersifat sosial. Dalam hal ini akad qardh menjadi bagian dari dana kebajikan, sehingga realisasi akad qardh yang bersifat murni sosial disajikan dalam Laporan Sumber Dan Penggunaan Dana Kebajikan. Akad qardh yang demikian ini secara praktis disebut dengan Qardhul Hasan. Dengan demikian dapat disimpulkan bahwa secara pragmatis qardh terbagi menjadi 2 yaitu qardh dan qardhul hasan. Qardh umumnya diimplentasikan dengan tidak berdiri sendiri, namun digabungkan dengan akad lain dalam satu produk perbankan. Sedangkan qardhul hasan, merupakan akad murni sosial yang dapat berdiri sendiri dalam suatu produk perbankan.

Wiroso (2011a), Nurhayati dan Wasilah (2013) dan IAI (2009) secara tersirat menunjukkan bahwa sumber dana qardh berasal dari berbagai produk pengumpulan dana yang dilakukan oleh pihak lembaga keuangan syariah, dan merupakan dana nasabah yang ditujukan untuk dikelola oleh pihak lembaga keuangan syariah dalam operasional utamanya. Sedangkan qardhul hasan, berumber dari dana hibah, infak, sedekah, denda ataupun pendapatan non-halal yang ditujukan untuk kepentingan sosial.

Namun demikian, MUI (2001) memberikan gambaran yang tidak membedakan antara qardh dan qardhul hasan sehingga sumber dana qardh juga tidak dibedakan secara spesifik, dimana sumber dana qardh berasal dari: (a) Bagian modal LKS; (b) Keuntungan LKS yang disisihkan; dan (c) Lembaga lain atau individu yang mempercayakan penyaluran infaknya kepada LKS.

Ayub (2007) menjelaskan bahwa $\mathrm{Mu}$ rabahah berasal dari kata "ribh" yang berarti tambahan, keuntungan atau laba. Antonio (2001), Karim (2010), Nurhayati dan Wasilah (2013), IAI (2009), dan Zaid (2009) mendefinisikan sebagai modal jual beli dengan menyebutkan harga perolehan, dan tambahan keuntungan yang disepakati. Usmani sebagaiman dikutip Widodo (2010) mendefinisikan Murabahah adalah se- 
bagai "is simply a sale", jual beli yang pembayarannya bisa secara tunai atau sesuai kesepakatan antar kedua belah pihak. Dengan demikian, Murabahah pada dasarnya merupakan bentuk jual beli dan bukan modal pembiayaan. Namun demikian UU No. 21 tahun 2008 dan pada tataran praktis menjadikan Murabahah sebagai bagian dari modal pembiayaan.

Zaid (2009) memaparkan bahwa rukun Murabahah adalah kedua belah pihak yang mengadakan transaksi mengetahui harga beli awal barang tersebut dan keuntungan yang diperoleh oleh penjual. Nurhayati dan Wasilah (2013), Yaya dkk. (2009) dan MUI (2000) secara spesifik menyebutkan rukun Murabahah terdiri dari: (1) Pelaku terdiri dari pembeli dan penjual, (2) Obyek jual beli berupa barang yang diperjualbelikan, (3) Ijab kabul/serah terima. Sedangkan Widodo (2010) yang mengutip Muammalat Institute, menambahkan harga barang (tsaman) sebagai rukun transaksi Murabahah.

Mustofa (2010) menjelaskan bahwa teori pertukaran sosial (Social Exchange Theory) berakar pada sosiologi behavioris. Tokoh-tokoh yang mengembangkan teori ini antara lain: Thibault dan Kelley (1959); Homans (1961), Emerson (1962), dan Blau (1964). Pandangan teori pertukaran sosial mengungkapkan bahwa dua orang individu yang mengadakan interaksi akan selalu mementingkan keuntungan dan meminimalkan kerugian (Muttaqin 2010).

Thibault dan Kelley sebagaimana dikutip Gumilar (2008) memandang bahwa teori ini menggambarkan hubungan interpersonal sebagai suatu transaksi dagang. Orang berhubungan dengan orang lain karena mengharapkan sesuatu yang dapat memenuhi kebutuhannya. Salah satu motivasi memenuhi kebutuhan sebagaimana diungkapkan oleh Nye, Sabatelli, Thibaut \& Kelley sebagaimana dikutip Sabatelli (2010) dan Homans yang dikutip Gumilar (2008) adalah adanya peningkatan nilai, dimana nilai tersebut merupakan sesuatu yang bernilai yang dikalikan dengan probabilitas untuk mendapatkan hasil (keuntungan) yang lebih besar.

Prinsip dasar pertukaran sosial adalah distributive justice yaitu aturan yang mengatakan bahwa sebuah imbalan harus sebanding dengan investasi. Proposisi yang terkenal dari Homans yang dikutip Mustofa (2010) sehubungan dengan prinsip tersebut berbunyi:
"Seseorang dalam hubungan pertukaran dengan orang lain akan mengharapkan imbalan yang diterima oleh setiap pihak sebanding dengan pengorbanan yang telah dikeluarkannya - makin tinggi pengorbanan, makin tinggi imbalannya - dan keuntungan yang diterima oleh setiap pihak harus sebanding dengan investasinya - makin tinggi investasi, makin tinggi keuntungan."

Akad transaksi Murabahah merupakan suatu akad transaksi pertukaran dua zat yang berbeda antara dua pihak dengan motif untuk mencari keuntungan. Karakteristik Murabahah yang menghendaki pengungkapan harga perolehan dan keuntungan yang disepakati oleh pihak penjual dan pembeli (Nurhayati dan Wasilah 2013). Pengungkapan tersebut menunjukkan bahwa harga jual (imbalan) sebanding dengan pengorbanan atau biaya perolehan (investasi) serta sebanding dengan keuntungan yang akan diperoleh atau disepakati. Hal ini memenuhi prinsip dasar pertukaran sosial.

Karim (2010) mengelempokkan akad Murabahah sebagai akad dengan kategori natural certainty contract yaitu akad dengan kepastian pembayaran, baik dari segi waktu dan jumlah pembayaran. Kontrak jenis ini mengikat pihak yang bertransaksi untuk saling menukar aset (baik dalam bentuk financial asset maupun real asset). Masingmasing pihak berdiri sendiri tanpa menimbulkan pertanggungan resiko. Pertukaran inilah yang menghasilkan transaksi jual beli. Dengan demikian, kontrak dengan kategori natural certainty sesuai dengan teori pertukaran sosial.

Zaid (2009) memaparkan bahwa ulama fiqih terdahulu mengkategorikan Murabahah sebagai bagian dari jenis jual beli amanah. Lebih lanjut, Munandar (2011) mendefinisikan jual beli sebagai tukar-menukar harta dengan harta, dengan tujuan memindahkan kepemilikan, dengan menggunakan ucapan ataupun perbuatan yang menunjukkan terjadinya transaksi jual beli.

Sifat dasar Murabahah adalah jual beli, sehingga Murabahah juga dikenakan syarat jual beli (Widodo 2010). Adapun persyaratan jual beli terdiri dari: (a) Barang yang menjadi obyek Murabahah harus sudah ada pada saat akad terjadi. (b) Barang yang menjadi obyek Murabahah telah sepenuhnya men- 
jadi milik dan dalam penguasaan penjual. (c) Transaksi Murabahah dilangsungkan tanpa ada syarat. (d) Penyerahan barang dilangsungkan pada saat akad dilaksanakan.

Antonio (2001) menambahkan syarat lain, yaitu: (1) Penjual wajib menyampaikan kepada pembeli semua hal yang berkaitan dengan pembelian dan kondisi barang, (2) Transaksi harus bebas riba', dan (3) Pembeli memiliki kebebasan untuk melakukan pilihan (khiyar). Selain syarat-syarat yang telah disebutkan, Badri (2009) dan IAI (2009) juga menekankan bahwa transaksi jual beli harus dengan obyek yang halal dan bebas dari unsur ketidakpastian (gharar) dan perjudian (maysir).

Berdasarkan berbagai pemaparan berkaitan dengan konsep Murabahah, sebagai suatu instrumen jual beli, maka beberapa esensi Murabahah antara lain: (a) Karakteristik fundamental Murabahah adalah adanya transparansi harga perolehan barang ditambah dengan laba yang disepakati antara penjual dengan pembeli (Widodo 2010; Rusyd 1986). Dengan demikian, Murabahah merupakan biaya ditambah keuntungan, dan bukan pinjaman uang melalui mekanisme pembiayaan. (b) Murabahah adalah jual beli, maka transaksinya harus memenuhi rukun dan syarat jual beli (Antonio 2001). (c) Murabahah harus bebas dari unsur riba' (Antonio 2001; ad Duwaisy 2009; Nurhayati dan Wasilah 2013). (d) Barang yang menjadi obyek Murabahah harus halal dan baik (IAI 2009; Karim 2010).

Nurhayati dan Wasilah (2013), Karim (2010), IAI (2009) Yaya, et al. (2009), Antonio (2001), dan MUI (2000b), secara ringkas telah mendefinisikan akad musyarakah sebagai akad kerjasama antara dua pihak atau lebih untuk suatu usaha tertentu, dimana masing-masing pihak memberi kan kontribusi dana/modal dan kerja dengan ketentuan bahwa keuntungan dibagi berdasarkan kesepakatan sedangkan apabila terjadi kerugian dibagi berdasarkan porsi kontribusi modal.

Jenis akad musyarakah dilihat dari aspek sifat akad, terbagi menjadi musyarakah permanen dan musyarakah menurun (musyarakah mutanaqisha) (IAI 2009). Musyarakah permanen adalah musyarakah dengan ketentuan bagian dana setiap mitra ditentukan sesuai akad dan jumlahnya tetap hingga akhir masa akad. Musyarakah menurun (musyarakah mutanaqisha) adalah musyarakah dengan ketentuan bagian dana entitas akan dialihkan secara bertahap kepada mitra sehingga bagian dana entitas akan menurun dan pada akhir masa akad mitra akan menjadi pemilik penuh usaha tersebut.

Sedangkan Nurhayati dan Wasilah (2013) membagi akad musyarakah menjadi beberapa jenis, diantaranya: (1) Musyarakah Kepemilikan (Syirkat Al-amlak), yaitu persekutuan (kerjasama partnership) antara dua orang atau lebih dalam kepemilikan salah satu barang dengan salah satu sebab kepemilikan. Musyarakah kepemilikan ini dibagi menjadi dua, yaitu: (a) Syirkah ikhtiyar atau perserikatan yang dilandasi pilihan orang yang berserikat. Sebagai contoh diantaranya dua orang sepakat berserikat membeli suatu barang. (b) Syirkah ijbari (perserikatan yang muncul secara paksa bukan atas keinginan orang yang berserikat), yaitu sesuatu yang ditetapkan menjadi milik dua orang atau lebih tanpa kehendak mereka, seperti harta warisan yang diterima karena adanya kematian dari salah satu keluarga. Status kepemilikan secara hukum menurut fuqaha adalah menjadi milik masing-masing yang berserikat sesuai haknya dan bersifat berdiri sendiri.

(2) Musyarakah Akad/Kontrak (Syirkat Al-'Uqud), yaitu kemitraan yang tercipta dengan kesepakatan dua orang atau lebih untuk bekerja sama dalam mencapai tujuan tertentu. Setiap mitra berkontribusi dana dan atau dengan bekerja, serta berbagai keuntungan dan kerugian. Syirkah jenis ini dapat dianggap kemitraan yang sesungguhnya karena pihak yang bersangkutan secara sukarela berkeinginan untuk membuat kerjasama investasi dan berbagi keuntungan dan resiko. Syirkah Al Uqud dapat dibagi menjadi sebagai berikut: (a) Syirkah Abdan, yaitu bentuk syirkah antara dua pihak atau lebih dari kalangan pekerja atau professional dimana mereka sepakat untuk bekerjasama mengerjakan suatu pekerjaan dan berbagi penghasilan yang diterima. Contoh: Akuntan, Dokter, dll. (b) Syirkah Wujuh, yaitu kerjasama antara dua pihak dimana masing-masing pihak sama sekali tidak menyertakan modal dan menjalankan usahanya berdasarkan kepercayaan pihak ketiga. Kerjasama ini hanya berbentuk kerjasama tanggungjawab bukan modal atau pekerjaan. (c) Syirkah Inan, yaitu sebuah persekutuan dimana posisi dan komposisi pihak-pihak yang terlibat di dalamnya adalah tidak sama, baik dalam modal maupun pekerjaan. Syirkah inilah yang yang se- 
jalan dengan istilah Musyarakah yang saat ini dipahami secara umum dalam transaksi perbankan secara umum. Jika dilihat dari sifat modal sepanjang kontrak maka Syirkah ini terdiri dari Musyarakah Permanen dan Musyarakah Menurun. (d) Syirkah Muwafadah, yaitu sebuah persekutuan dimana posisi dan komposisi pihak-pihak yang terlibat didalamnya harus sama, baik dalam hal modal, pekerjaan, agama, keuntungan maupun resiko kerugian. (e) Syirkah Al Mudharabah, yaitu bentuk kerjasama dua pihak akad kerjasama usaha antara dua pihak dimana pihak pertama (pemilik dana) menyediakan seluruh dana, sedangkan pihak kedua (pengelola dana) bertindak selaku pengelola, dan keuntungan usaha dibagi di antara mereka sesuai kesepakatan sedangkan kerugian finansial hanya ditanggung oleh pemilik dana.

Terkait pola distribusi keuntungan dan kerugian dalam akad musyrakah, MUI (2000e) melalui FATWA DSN Nomor: 15/ DSN-MUI/IX/2000 tentang Prinsip Distribusi Bagi Hasil terdiri dari: (1) Prinsip Bagi Untung (Profit \& Loss Sharing) dimana dasar pembagian adalah laba neto (net profit) yaitu laba bruto dikurangi beban yang berkaitan dengan pengelolaan modal mudharabah. (2) Prinsip Bagi Hasil (Nett Revenue Sharing) dimana dasar pembagian hasil usaha adalah laba bruto (gross profit) bukan total pendapatan usaha (omzet).

Lebih lanjut MUI (2000b) memberikan perhatian khusus dalam pola pembagian keuntungan, mitra harus membagikan keuntungan secara proporsional atas dasar seluruh keuntungan dan tidak ada jumlah yang ditentukan di awal yang ditetapkan bagi seorang mitra. Sedangkan dalam hal distribusi kerugian dibagi secara proporsional berdasarkan porsi modal masing-masing mitra selama kerugian ini merupakan kerugian yang bersifat normal, bukan karena kelalaian mitra.

Nurhayati dan Wasilah (2013), Wiroso (2011a) mendifinisikan ijarah sebagai akad pemindahan hak guna (manfaat) atas suatu barang atau jasa, dalam waktu tertentu dengan pembayaran upah sewa (ujrah), tanpa diikuti dengan pemindahan kepemilikan atas barang itu sendiri. Prinsip ijarah sama dengan prinsip jual beli, namun perbedaannya terletak pada obyek transaksinya, bila pada jual beli objek transaksinya adalah barang, maka pada ijarah obyek transaksinya adalah jasa atau manfaat suatu obyek.
MUI (2000c) mendifinisikan al-Ijarah adalah "akad pemindahan hak guna (manfaat) atas suatu barang atau jasa dalam waktu tertentu melalui pembayaran sewa atau upah, tanpa diikuti dengan pemindahan kepemilikan barang itu sendiri." Dengan demikian, dalam akad ijarah tidak ada perubahan kepemilikan, tetapi hanya pemindahan hak guna saja dari yang menyewakan kepada penyewa.

Berdasarkan fatwa tersebut dan dikaitkan dengan transaksi ekonomi di perbankan maka, ijarah merupakan pembiayaan bank untuk pengadaan barang ditambah keuntungan yang disepakati dengan sistem pembayaran sewa tanpa diakhiri dengan pemilikan. Dalam kegiatan ekonomi pada umumnya dikenal dengan nama operational lease (sewa guna usaha), dimana pihak bank memberikan kesempatan kepada nasabah atau penyewa untuk memperoleh manfaat dari barang untuk jangka waktu tertentu, dengan ketentuan nasabah akan membayar sejumlah uang (sewa) pada waktu yang disepakati secara periodik. Apabila telah habis jangka waktunya, benda atau barang yang dijadikan obyek al-Ijarah tersebut tetap menjadi milik bank.

Perkembangan transaksi syariah dan pemikiran ekonomi syariah juga memberikan dukungan terhadap perkembangan inovasi transaksi syariah. Implementasi akad ijarah pada saat ini telah berkembang dengan sangat pesat. Zaky (2013) memberikan gambaran secara ringkas jenis akad ijarah yang tengah berjalan antara lain tampak pada gambar 1 .

Berdasarkan skema yang tampak pada gambar 1, jenis ijarah dapat dibagi berdasarkan sudut pandang yang digunakan. Berdasarkan jenis obyek ijarah, maka dibagi menjadi: (1) Ijarah Fee yaitu akad ijarah yang menjadikan jasa sebagai obyek manfaat yang disewakan. Pendapatan yang diperoleh berupa fee atas jasa yang telah diberikan oleh pemilik obyek kepada penyewa. (2) Ijarah Asset yaitu akad ijarah yang menjadi aset sebagai obyek manfaat yang disewakan. Aset yang dapat disewakan adalah aset berwujud dan yang tidak berwujud. Ijarah Aset Berwujud menggunakan aset berwujud sebagai obyek sewa-menyewa. Termasuk kategori ini antara lain: (a) Jual-Ijarah, merupakan kombinasi antara akad penjualan yang dilanjutkan dengan sewa menyewa. (b) Ijarah, merupakan akad sewa menyewa tanpa perpindahan kepemilikan (operating lease). (c) Al-Ijarah 


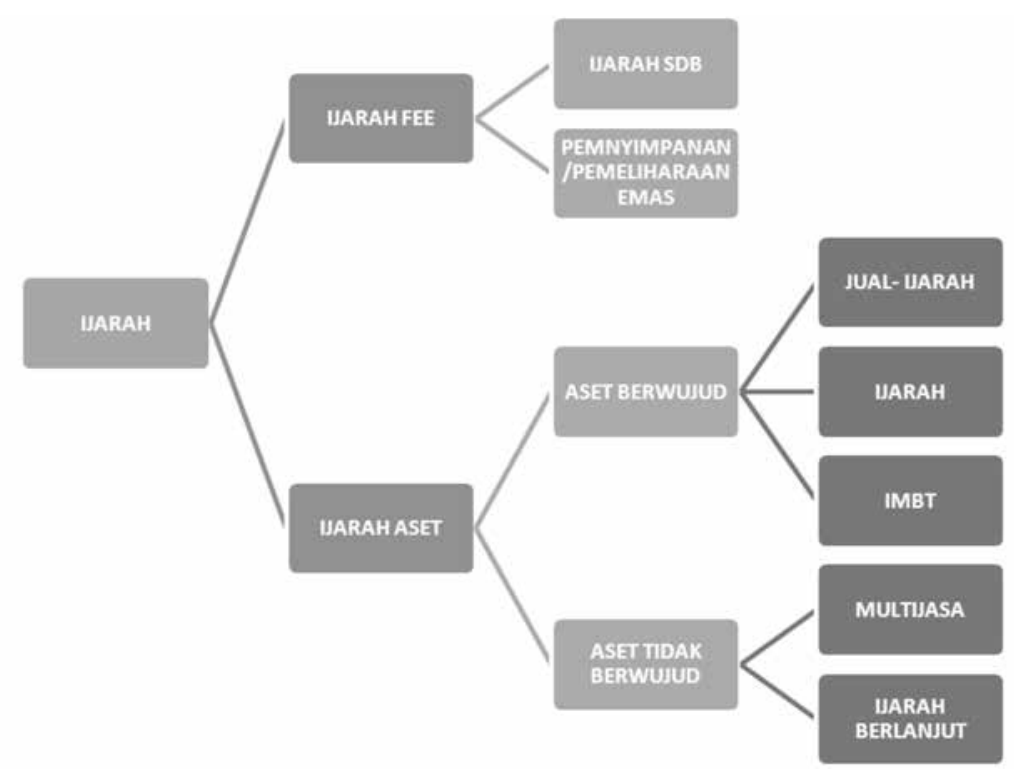

Gambar 1. Jenis Akad Ijarah

Al-Muntahiyah Bi Al-Tamlik (IMBT), MUI (2002) menjelaskan merupakan akad sewamenyewa yang disertai dengan akad wa'ad untuk opsi kemungkinan dilakukan perpindahan kepemilikan setelah selesai masa sewa. Ijarah Aset Tidak Berwujud, menggunakan aset tidak berwujud sebagai obyek sewa-menyewa. Termasuk dalam kategori ini antara lain: (a) Ijarah Berlanjut, bentuk akad sewa menyewa dimana suatu entitas menyewakan lebih lanjut kepada pihak lain atas aset yang sebelumnya disewa dari pemilik. (b) Multi Jasa, bentuk pengembangan dalam implementasi akad ijarah berlanjut, umumnya digunakan dalam transaksi pendidikan, ibadah haji dan pernikahan.

\section{METODE}

Penelitian ini menggunakan pendekatan kualitatif dengan metode studi kepustakaan (library research). Eferin et al. (2004:24) menilai bahwa penelitian kualitatif lebih menekankan pemahaman yang bersifat kualitatif yang mendalam terhadap fenomena sosial yang diteliti. Lebih lanjut, Indriantoro dan Supomo (2002:12) menjelaskan bahwa penelitian kualitatif memberikan penekanan pada pemahaman masalah sosial berdasarkan kondisi realitas, kompleks dan terperinci.

Hasan (2002:11) menjelaskan bahwa metode penelitian kepustakaan merupakan penelitian yang dilaksanakan dengan menggunakan berbagai literatur, seperti buku, ju- rnal, maupun catatan penelitian dari penelitian terdahulu. Studi kepustakaan juga dapat dimaknai sebagai suatu bentuk metodologi penelitian yang menekankan pada pustaka sebagai obyek studi. Namun demikian, bukan berarti penelitian ini menekankan pada fisik karya tersebut, akan tetapi pada gagasan ataupun esensi yang terkandung dalam karya tersebut.

Dengan demikian, studi kepustakaan dilakukan dengan melakukan analisis komparatif maupun historis atas suatu masalah yang menjadi topik dari gagasan ataupun konsepsi yang telah ada dengan tetap mengacu pada bidang keilmuan yang dikaji. Penelitian ini mengkaji alternatif solusi yang ditawarkan DSN MUI melalui Fatwa DSN MUI Nomor: 31/DSN-MUI/VI/2002 tentang pengalihan hutang. Analisis utama peneliti lakukan pada pola transaksi dan akad yang ditawarkan yang kemudian peneliti kaitkan dengan berbagai literatur yang membahas masing-masing akad serta dampak pada perlakuan akuntansi yang timbul setelahnya.

Instrumen penelitian merupakan semua alat yang digunakan untuk mengumpulkan, memeriksa, menyelidiki suatu masalah, atau mengumpulkan, mengolah, menganalisa dan menyajikan data-data secara sistematis serta objektif dengan tujuan memecahkan suatu persoalan atau menguji suatu hipotesis (Adhon 2008). Dengan demikian, seluruh alat yang dapat mendukung suatu penelitian disebut instrumen penelitian. 
Sugiyono (2005:60) menyatakan bahwa peneliti kualitatif sebagai human instrument berfungsi menetapkan fokus penelitian, memilih informan sebagai sumber data, melakukan pengumpulan data, menilai kualitas data, analisis data, menafsirkan data, dan membuat kesimpulan atas temuannya.

Penelitian studi kepustakaan juga menggunakan instrumen penelitian yang disesuaikan dengan metode analisis yang digunakan, namun demikian secara umum instrumen penelitian yang digunakan untuk melakukan analisis dalam studi kepustakaan antara lain: doktrin, postulat, teori yang sesuai dengan bidang keilmuan, dan subyektifitas (judgement) peneliti. Pada penelitian ini menggunakan human instrumen yang ditunjang dengan teori atau konsep pengalihan utang dalam transaksi syariah di lembaga keuangan syariah.

Menurut Yin (2002:103), sumber data dalam penelitian digunakan untuk mengumpulkan data. Data yang digunakan dalam penelitian adalah data sekunder. Data sekunder merupakan sumber data yang tidak secara langsung memberikan data kepada pengumpul data, misalnya melalui orang lain atau dokumen yang ada (Sugiyono 2005:62). Sumber data menurut Yin (2002:103-118) terdiri dari dokumen, rekaman arsip, wawancara, observasi, observasi partisipan dan perangkat fisik. Penelitian ini menggunakan dokumentasi untuk mendapatkan data yang digunakan dalam studi literatur atau studi kepustakaan.

Data sekunder yang didapat peneliti adalah data yang diperoleh peneliti melalui studi dokumentasi obyek, rekaman arsip, perangkat fisik dan studi literatur atau pustaka. Menurut Yin (2002:110-118) bahwa dokumen, rekaman arsip dan perangkat fisik yang berupa perangkat lunak maupun beberapa perangkat keras obyek penelitian menghasilkan data-data historis operasional dan kinerja obyek penelitian. Penelitian ini menggunakan berbagai dokumen terkait perbankan syariah, diantaranya dokumentasi operasional pembiayaan take over bank syariah, Fatwa DSN MUI dan Standar Akuntansi Keuangan (SAK) Syariah.

Yuwinda (2009) menjelaskan bahwa studi pustaka merupakan teknik pengumpulan data dengan mempelajari dan menganalisa suatu sumber pustaka baik berupa buku, artikel, maupun penelitian sebelumnya. Hasan (2002:45) menyatakan bahwa studi pustaka dilaksanakan oleh peneliti dengan mendalami, mencermati, menelaah dan mengidentifikasi pengetahuan dalam kepustakaan. Pada penelitian ini, literatur yang dipilih dalam studi pustaka antara lain jurnal ilmiah, buku, SAK Syariah, Fatwa DSN MUI serta berbagai artikel yang peneliti akses dari internet.

Menurut Sugiyono (2005:88), analisis data adalah proses mencari dan menyusun secara sistematis data yang diperoleh dari hasil wawancara, catatan lapangan, dan bahan-bahan lain, sehingga dapat mudah dipahami, dan temuannya dapat diinformasikan kepada orang lain. Metode yang peneliti lakukan dalam melakukan analisis data antara lain: (a) Mengumpulkan data pendukung melalui berbagai teknik pengumpulan data, sebagaimana telah dijelaskan pada bagian sebelumnya. (b) Peneliti melakukan analisis data dengan menggunakan teknik analisis komparatif. Dalam hal ini, peneliti melakukan komparasi konsep yang telah dibangun para pakar dalam Fatwa DSN MUI Nomor: 31/DSN-MUI/VI/2002 tentang pengalihan hutang dengan berbagai data dan situasi sosial yang sesuai dengan permasalahan penelitian ini. (c) Penarikan simpulan atas hasil penelitian. Proses penarikan simpulan ini dilakukan oleh peneliti dengan mengintepretasikan berbagai situasi sosial yang berkaitan dengan masalah penelitian sehingga dihasilkan kajian mendalam terkait alternatif yang ditawarkan dalam Fatwa DSN MUI Nomor: 31/DSN-MUI/VI/2002 tentang pengalihan hutang.

\section{HASIL DAN PEMBAHASAN}

Perkembangan dunia perbankan syariah mendorong perkembangan variasi transaksi yang semakin kompleks. Hal ini berdampak pada kebutuhan suatu model transaksi yang tetap menjaga kepatuhan pada prinsip syariah. Kondisi lain yang terjadi adalah keberadaan dual banking system yang berkembang di Indonesia menjadikan kompleksitas transaksi semakin meningkat. Bank Indonesia (2011) menyatakan bahwa salah satu motif utama masyarakat untuk memanfaatkan jasa perbankan syariah adalah menghindari riba'.

Dorongan akan kebutuhan sistem perbankan syariah memberikan dampak pula kepada masyarakat yang telah terikat pada kontrak dalam transaksi perbankan konvensional. DSN-MUI (2002) telah memetakan beberapa situasi yang mendorong kebutuhan suatu akad yang mampu menampung 
perpindahan transaksi dari perbankan konvensional ke perbankan syariah, antara lain: (a) Kebutuhan bentuk jasa pelayanan keuangan yang menjadi kebutuhan masyarakat yang mampu membantu masyarakat untuk mengalihkan transaksi non-syariah yang telah berjalan menjadi transaksi yang sesuai dengan syariah; (b) Kebutuhan akan lembaga keuangan syariah (LKS) yang segera merespon kebutuhan masyarakat tersebut dalam berbagai produknya melalui akad pengalihan utang oleh LKS; (c) Kebutuhan agar akad tersebut dilaksanakan sesuai dengan Syariah Islam, sehingga diperlukan fatwa mengenai peralihan utang untuk dijadikan pedoman.

Sesuai dengan kondisi tersebut maka dibutuhkan model pembiayaan yang menggunakan suatu akad berupa peralihan utang (hawalah). Akad hawalah merupakan pengalihan utang dari pihak yang berutang kepada pihak yang wajib membayar utang tersebut. Jika mendasarkan pada definisi tersebut, akad hawalah menunjukkan bahwa akad ini merupakan satu kesatuan akad yang secara esensi merupakan perpaduan dari beberapa akad.

Oleh karena itu, aplikasi akad hawalah pada lembaga keuangan syariah tidak dapat berdiri sendiri melainkan diwujudkan dalam kombinasi akad (hybrid contract). Mingka (2013a) menekankan bahwa model pembiayaan take over yang diterapkan merupakan bagian dari hybrid contract, dimana sejatinya secara akad adalah satu kesatuan akad yang tidak dapat dipisahkan yang terdiri dari beberapa akad. Lebih lanjut, Mingka (2013c) menekankan esensi kebutuhan hybrid contract antara lain: (a) Keterkaitan aspek perpajakan dalam akad transaksi syariah. (b) Keterkaitan akuntansi, terutama dalam as- pek akad manakah yang menjadi penekanan dalam pencatatannya. (c) Kebutuhan dalam inovasi produk yang semakin kompleks. (d) Keterkaitan dalam biaya hukum yang ditimbulkan apabila akad terpisah.

Sejalan dengan kebutuhan tersebut, maka DSN MUI telah memberikan fatwa DSN MUI Nomor: 31/DSN-MUI/VI/2002 tentang pengalihan hutang dan memberikan beberapa alternatif dengan beberapa kombinasi akad yang dapat diterapkan.

Perkembangan dunia perbankan syariah menuntut inovasi pengembangan produk melalui kombinasi berbagai akad yang telah ada dengan tetap menjaga kesesuaian dengan prinsip syariah terkait transaksi. Al Imrani sebagaimana dikutip oleh Mingka (2013b) mendefinisikan hybrid contract yaitu:

"Kesepakatan dua pihak untuk melaksanakan suatu akad yang mengandung dua akad atau lebih - seperti jual beli dengan sewa menyewa, hibah, wakalah, qardh, muzara'ah, sahraf (penukaran mata uang), syirkah, mudharabah... dst. - sehingga semua akibat hukum akad-akad yang terhimpun tersebut, serta semua hak dan kewajiban yang ditimbulkannya dipandang sebagai satu kesatuan yang tidak dapat dipisah-pisahkan, sebagaimana akibat hukum dari satu akad."

Berdasarkan definisi tersebut tersirat pada dasarnya hybrid contract terkadang tidak dapat dihindari apabila suatu transaksi yang terjadi dari penggabungan lebih dari satu akad namun menjadi satu kesatuan yang tidak terlepaskan. Namun demkian, Mingka (2013b) menilai hybrid contract pada

Tabel 1. Kombinasi Kontrak (Hybrid Contract) Alternatif Take Over

\begin{tabular}{cl}
\hline ALTERNATIF & \multicolumn{1}{c}{ AKAD } \\
\hline I & $\begin{array}{l}\text { a. Akad Qardh } \\
\text { b. Akad Murabahah } \\
\text { II }\end{array}$ \\
III & $\begin{array}{l}\text { a. Akad Syirkah al milk (Kepemilikan Bersama) } \\
\text { b. Akad Murabahah } \\
\text { a. Akad Ijarah } \\
\text { IV }\end{array}$ \\
& b. Akad Qardh \\
a. Akad Qardh \\
b. Akad Ijarah Muntahiyah bi al Tamlik
\end{tabular}

Sumber: fatwa DSN MUI Nomor: 31/DSN-MUI/VI/2002 
tataran praktis di perbankan syariah Indonesia masih menimbulkan perdebatan akibat dari perbedaan pemahaman terkait boleh tidaknya melakukan penggabungan akad. Lebih lanjut, Mingka (2013a dan 2013b) menilai bahwa tidak semua penggabungan akad itu terlarang. Batasan larangan terhadap penggabungan akad adalah hanya terbatas pada akad utang-piutang yang digabung dengan jual beli.

Larangan tersebut juga hadist riwayat Ahmad berikut yang menyatakan: "Nabi melarang menggabungkan akad jual beli dan akad qardh". Sebagaimana telah dijelaskan sebelumnya bahwa ijarah merupakan bagian dari akad jual beli. Ijarah pada hakekatnya adalah akad jual beli jasa. Sejalan dengan hadist tersebut, Accounting \& Auditing Organization of Islamic Finance Institution (AAOIFI) dalam panduan lembaga keuangan syariah melarang penggabungan akad qardh dan ijarah (Tarmizi 2012). Hal ini tertuang dalam pasal 19 tentang Qardh ayat (7):

"Lembaga keuangan syariah tidak diperbolehkan mensyaratkan akad ba'i (jual beli), akad ijarah, atau akad mu'awadhah lainnya yang digabung dalam akad qard. Karena dalam jual/sewa biasanya pihak debitur sering menerima harga diatas harga pasar dan ini merupakan sarana untuk terjadi riba' (pinjaman yang mendatangkan keuntungan)."

Pasal (25) tentang penggabungan beberapa akad dalam satu akad ayat (4):

"Persyaratan boleh menggabung beberapa akad adalah apabila tidak ada larangan syariat. Maka tidak boleh menggabung antara akad qard dengan ba'i karena penggabungan qard dengan ba'i merupakan sarana terjadinya riba'. Dan juga ijma' ulama bahwa seorang kreditur yang mensyaratkan kepada debitur bahwa debitur harus menyewakan kembali rumahnya kepada kreditur maka akadnya dihukumi batal dan haram."

Padahal didalam perkembangan implementasi transaksi syariah di perbankan syariah tidak terbatas pada penggabungan akad qardh dan ijarah saja, sebagaimana Mingka (2013b) menjelaskan bahwa jenis penggabungan akad dapat terdiri dari: (1) Multi Akad yang mukhtalithah (bercampur) yang memunculkan nama baru. (2) Hybrid Contract yang mujtami'ah/mukhtalitah dengan nama akad baru, tetapi menyebut nama akad yang lama. (3) Hybrid contract, yang akad-akadnya tidak bercampur dan tidak melahirkan nama akad baru, tetapi nama akad dasarnya tetap ada dan dipraktekkan dalam suatu transaksi. (4) Hybrid Contract yang mutanaqidhah (akad-akadnya berlawanan). Bentuk ini dilarang dalam syariah. Sebagai contoh menggabungkan akad jual beli dan pinjaman (bay' wa salaf). Menggabungkan qardh wal Ijarah dalam satu akad. Dan contoh lain adalah menggabungkan qardh dengan janji hadiah.

Selain mendasarkan pada berbagai bentuk penggabungan akad yang sejatinya dapat dimaknai lebih luas, Mingka (2013a) menilai keberadaan hybrid contract juga diperlukan dengan alasan berikut: (1) Hybrid contracts terkait dengan pajak. (2) Hybrid contracts sangat terkait dengan inovasi produk. (3) Hybrid contracts sangat terkait dengan kebijakan regulasi dan standar akuntansi. (4) Hybrid contracts sangat terkait dengan efisiensi dalam implementasi perbankan.

\section{Alternatif Pertama: Kombinasi Akad Qa- rdh dan Murabahah}

\section{ALTERNATIF I}

1. LKS memberikan qardh kepada nasabah. Dengan qardh tersebut nasabah melunasi kredit (utang)-nya; dan dengan demikian, aset yang dibeli dengan kredit tersebut menjadi milik nasabah secara penuh.

2. Nasabah menjual aset dimaksud angka 1 kepada LKS, dan dengan hasil penjualan itu nasabah melunasi qardh-nya kepada LKS.

3. LKS menjual secara murabahah aset yang telah menjadi miliknya tersebut kepada nasabah, dengan pembayaran secara cicilan.

4. Fatwa DSN Nomor: 19/DSN-MUI/ IV/2001 tentang al-Qardh dan Fatwa DSN Nomor: 04/DSN-MUI/IV/2000 tentang murabahah berlaku pula dalam pelaksanaan Pembiayaan Pengalihan Utang sebagaimana dimaksud alternatif I ini. (MUI 2002)

Alternatif pertama merupakan kombinasi dari akad utang-piutang yang dilanjut- 
kan dengan akad jual beli. Dengan demikian akad ini menggabungkan akad tabarru' dengan akad tijari. Implikasi akad ini dapat dirasakan dalam 2 sudut pandang, yakni kesesuaian prinsip syariah (sharia compliance) dan perlakuan akuntansi.

Akad utang-piutang (qardh) terjadi antara nasabah dengan bank syariah, dimana tujuan utama penyaluran dana oleh bank adalah untuk membantu nasabah melunasi utang terhadap bank konvensional. Dengan pelunasan ini maka nasabah memiliki secara penuh aset tersebut. Setelah aset dikuasai maka nasabah memiliki hak penuh terhadap asetnya sehingga diharapkan nasabah menjual aset tersebut kepada bank syariah. Dengan demikian, bank syariah dapat mengambil alih hak kepemilikan aset tersebut sedangkan nasabah dapat melunasi utang kepada bank syariah dari hasil penjualan aset. Berhubung aset tersebut sejatinya dibutuhkan oleh nasabah, maka bank syariah menjual kembali aset tersebut kepada nasabah dengan menggunakan akad murabahah.

Berdasarkan penjelasan alternatif tersebut, tampak beberapa hal yang terkait langsung dengan kepatuhan pada prinsip syariah, diantaranya: (a) Waktu pelaksanaan akad. Alternatif ini menimbulkan kerancuan terkait waktu yang tepat penentuan akad. Jika merujuk pada pendapat Mingka (2013c) maka sejatinya akad ini adalah satu kesatuan akad, maka timbul kesulitan dalam hal implementasi apabila seluruh akad yang dikombinasikan, dilaksanakan secara bersamaan dalam satu akad. (b) Perbedaan karakter akad. Masing-masing akad memiliki karakteristik akad yang menghendaki rukun berbeda, sehingga memiliki risiko pelanggaran kepatuhan syariah yang besar apabila disatukan. Akad antara LKS dengan nasabah pada alternatif 1 ini terdiri dari qa$r d h$ dan jual beli yang terjadi sebanyak dua kali. (c) Terjadi kombinasi akad yang terlarang. Alternatif I menghendaki hybrid contract yang mengandung akad qardh dan jual beli. Sebagaimana penjelasan Tarmizi (2012) dan Mingka (2013b) bahwa kombinasi akad yang dilarang adalah terjadinya akad qardh dan jual beli dalam satu transaksi. Mingka (2013c) menjelaskan bahwa hybrid contract pada alternatif I ini harus dimaknai sebagai satu akad. Dengan demikian, telah terbukti bahwa akad ini merupakan kombinasi yang terlarang. (d) Terjadi Ba'i al inah. Alternatif I menghendaki nasabah menjual obyek kepada LKS untuk melunasi qardh, kemudian LKS akan menjual kembali secara murabahah kepada nasabah. Dengan demikian telah jelas bahwa bentuk transaksi yang demikian inilah yang termasuk jual beli al inah. Muawiah (2008) menekankan pada waktu obyek tersebut jatuh kembali kepada pihak penjual maka disitulah terhitung sebagai jual beli dengan cara al-inah. Selain itu, IAI (2009), Badri (2010) dan Tarmizi (2012) menjelaskan bahwa karakteristik transaksi syariah adalah melarang adanya jual beli inah.

Selain aspek kepatuhan syariah, Alternatif I memberikan implikasi yang cukup rumit pada aspek akuntansi yang diterapkan. Standar akuntansi syariah yang ada di Indonesia hingga saat ini belum mengatur tentang akad hiwalah. Akad hiwalah pada dasarnya merupakan kombinasi dari berbagai akad dasar yang telah diatur oleh PSAK Syariah, sehingga Mingka (2013c) menyatakan perlakuan akuntansi yang dapat diterapkan merujuk pada akad yang paling dominan. Namun demikian, peneliti menilai bahwa perlakuan akuntansi tidak didasarkan pada akad semata, namun pada substansi transaksi yang terjadi. Meskipun secara akad hanya terjadi dua akad, namun demikian pada sisi LKS terjadi beberapa transaksi yang menghendaki perlakuan akuntansi berbeda.

Tabel 2. Jurnal untuk Alternatif I Akad Hawalah

\begin{tabular}{llll}
\hline $\begin{array}{c}\text { LKS Memberikan } \\
\text { Utang ke Nasabah }\end{array}$ & $\begin{array}{c}\text { LKS Membeli } \\
\text { Obyek dari } \\
\text { Nasabah }\end{array}$ & $\begin{array}{c}\text { LKS Menerima } \\
\text { Pelunasan dari } \\
\text { Nasabah }\end{array}$ & $\begin{array}{c}\text { LKs Sebagai Penjual } \\
\text { dalam Murabahah }\end{array}$ \\
\hline (D) Piutang Nasabah & (D) Persediaan & (D) Kas & (D) Piutang Murabahah \\
(K) Kas & (K) Kas & (K) Piutang Nasabah & $\begin{array}{l}\text { (K) Margin Murabahah } \\
\text { Tangguh }\end{array}$ \\
& & & (K) Persediaan \\
\hline
\end{tabular}


Berdasarkan pola transaksi yang terjadi, maka peneliti menilai terdapat beberapa perlakuan akuntansi yang berkaitan dengan transaksi pada alternatif I, sebagaimana tampak pada tabel 2:

Apabila alternatif I dilaksanakan, maka keempat jurnal tersebut digunakan untuk mengakui terjadinya transaksi hawalah. Setelah tahap pengakuan maka selanjutnya dapat dilakukan penjurnalan angsuran akad murabahah sebagaimana ketentuan PSAK 102 tentang Murabahah. Namun demikian, jurnal ideal ini akan sulit dilaksanakan oleh LKS, apabila LKS tidak pernah melakukan transaksi jual beli secara riil. Muawiyah (2008) juga menilai pada tataran praktis, transaksi jual beli secara sempurna tidak pernah dilaksanakan, sehingga akad jual beli yang dilaksanakan hanya merupakan bagian dari upaya al hielah (tipu daya) transaksi jual beli. Dengan demikian, sering kali transaksi yang diakui sebagai titik pengakuan adalah pada saat LKS melakukan murabahah dengan nasabah, dan itupun tanpa mempertimbangkan keberadaan akun persediaan. Peneliti menilai perlakuan akuntansi yang umum digunakan ini adalah sejalan dengan pendapat dari Mingka (2013c) yang menilai perlakuan akuntansi yang tepat adalah yang paling dominan.

\section{Alternatif Kedua: Kombinasi Akad Sy- irkah dan Murabahah}

\section{ALTERNATIF II}

1. LKS membeli sebagian aset nasabah, dengan seizin LKK; sehingga dengan demikian, terjadilah Syirkah al-milk antara LKS dan nasabah terhadap aset tersebut.

2. Bagian aset yang dibeli oleh LKS sebagaimana dimaksud angka 1 adalah bagian aset yang senilai dengan utang (sisa cicilan) nasabah kepada LKK.

3. LKS menjual secara murabahah bagian aset yang menjadi miliknya tersebut ke- pada nasabah, dengan pembayaran secara cicilan.

4. Fatwa DSN Nomor: 04/DSN-MUI/ IV/2000 tentang murabahah berlaku pula dalam pelaksanaan Pembiayaan Pengalihan Utang sebagaimana dimaksud dalam alternatif II ini. (MUI 2002)

Berdasarkan alternatif yang ditawarkan oleh DSN tersebut menunjukkan pada dasarnya akad yang terjadi antara LKS dengan nasabah hanya transaksi jual beli. Namun demikian, jual beli tersebut menjadi bagian dalam suatu akad. Zaky (2013) dan Mingka (2013b) menjelaskan bahwa syirkah al milk secara prinsip merupakan bentuk kepemilikan bersama dimana proses pembentukannya dapat melalui proses jual beli. Alternatif II ini menggunakan model jual beli dalam pembentukan akad syirkah al milk. Secara ringkas akad dan transaksi yang terjadi dalam alternatif II tampak pada tabel 3:

Jika dibandingkan dengan alternatif I maka alternatif II relatif lebih sederhana, baik dari segi akad maupun dari segi transaksi yang dilaksanakan. Namun demikian, peneliti tetap memberikan perhatian terhadap aspek kesesuaian syariah dan implikasi terhadap perlakuan akuntansi yang sesuai.

LKS harus memperhatikan kepatuhan syariah dalam implementasi akad syirkah al milk. LKS dalam hal ini selaku pembeli harus melakukan transaksi jual beli kepada nasabah selaku penjual. Dengan demikian hal ini akan berimplikasi pada perlakuan akuntansi, dimana LKS harus mengakui terjadinya peningkatan aset, setidaknya hingga transaksi jual beli telah dilakukan secara sempurna. Sehingga LKS dapat melakukan pencatatan:

Setelah aset telah mutlak menjadi milik LKS secara sempurna, maka LKS dapat melakukan akad murabahah. Implikasi akuntansi untuk transaksi selanjutnya telah diatur sebagaimana PSAK 102 tentang murabahah. Dengan demikian, alternatif ini hanya

Tabel 3. Akad dan Transaksi dalam Alternatif II Akad Hiwalah

\begin{tabular}{ll}
\hline \multicolumn{1}{c}{ Akad } & \multicolumn{1}{c}{ Transaksi } \\
\hline 1. Syirkah al milk & $\begin{array}{l}\text { 1. Jual Beli: LKS membeli sebagian obyek dari nasabah. } \\
\text { Hak milik LKS sebatas bagian yang dijual. }\end{array}$ \\
2. Murabahah & $\begin{array}{l}\text { 2. Jual Beli: Bagian milik LKS dijual secara murabahah } \\
\text { kepada nasabah. }\end{array}$ \\
\hline
\end{tabular}


Tabel 4. Jurnal untuk Alternatif II

\begin{tabular}{lll}
\hline (D) Aset/Persediaan & $\mathrm{xxx}$ & Keterangan: \\
(K) Kas & $\mathrm{xxx}$ & Nilai aset hanya sebesar porsi kepemilikan LKS.
\end{tabular}

dapat diimplementasikan untuk pengalihan utang yang dihasilkan dari kepemilikan aset, tidak dapat dalam bentuk utang-piutang berupa uang.

Sebagaimana alternatif I, alternatif II juga memiliki permasalahan dalam hal indikasi terjadinya al hielah untuk pengalihan utang melalui transaksi jual beli. Kondisi ini diperparah dengan terjadinya ba'i al inah antara LKS dengan nasabah, dimana LKS membeli dari nasabah kemudian dilanjutkan dengan menjual kembali kepada nasabah dengan harga lebih tinggi dari perolehan.

Terkait waktu pelaksanaan akad dalam alternatif II, Mingka (2013b) memberi penekanan pada kebolehan terjadinya percampuran dua akad dalam satu transaksi sepanjang transaksi tersebut bukan termasuk dalam kategori yang dilarang. Tarmizi (2012) dan Badri (2010) memberikan penekanan bahwa transaksi qardh yang bergabung dengan transaksi jual beli adalah terlarang. Akad yang digunakan dalam alternatif II ini merupakan kombinasi akad jual beli, maka tidak termasuk dalam kategori yang terlarang tersebut. Namun demikian, tetap menjadi perhatian adalah sifat akad harus senantiasa independen serta substansi terjadinya akad, apakah murni untuk jual beli ataukah sebagai bentuk al hielah atas utang piutang dengan tambahan.

\section{Alternatif Ketiga: Kombinasi Akad Qardh dan Ijarah}

\section{ALTERNATIF III}

1. Dalam pengurusan untuk memperoleh kepemilikan penuh atas aset, nasabah dapat melakukan akad ijarah dengan LKS, sesuai dengan Fatwa DSN-MUI Nomor: 09/DSN-MUI/IV/2002.

2. Apabila diperlukan, LKS dapat membantu menalangi kewajiban nasabah dengan menggunakan prinsip al-Qardh sesuai Fatwa DSN-MUI Nomor 19/DSN-MUI/ IV/2001.

3. Akad ijarah sebagaimana dimaksudkan angka 1 tidak boleh dipersyaratkan dengan (harus terpisah dari) pemberian talangan sebagaimana dimaksudkan angka 2.
Besar imbalan jasa ijarah sebagaimana dimaksudkan angka 1 tidak boleh didasarkan pada jumlah talangan yang diberikan LKS kepada nasabah sebagaimana dimaksudkan angka 2. (MUI 2002)Alternatif III dibangun atas dasar dua akad utama dalam dua transaksi yaitu: (1) LKS memberikan jasa membantu proses pengurusan kepemilikan aset, (2) LKS dapat memberikan dana talangan untuk melunasi utang nasabah. Jika merujuk pada model transaksi yang ditawarkan, maka sejatinya nasabah yang memiliki utang kepada lembaga konvensional meminta bantuan LKS untuk menjadikan nasabah memiliki aset secara utuh namun cukup hanya berurusan dengan LKS.

Alternatif III dikembangkan dengan melakukan kombinasi akad ijarah dan qa$r d h$, sehingga tingkat kehati-hatian dalam implementasi harus ditingkatkan. Tarmizi (2012), Mingka (2013b) dan Zaky (2013) juga menekankan bahwa akad qardh dan ijarah apabila disatukan dalam satu transaksi termasuk dalam kategori transaksi terlarang. Ijarah pada dasarnya juga merupakan akad jual beli, namun dalam bentuk jual beli jasa. Oleh karena itu, MUI (2002) memberikan tekanan khusus agar kedua akad ini harus terpisah dan tidak boleh dilaksanakan secara bersamaan serta bergantung.

Upaya yang harus dilakukan dalam implementasi akad ini adalah dengan membuat dua akad secara terpisah, dimana secara ekonomi menimbulkan implikasi inefisiensi biaya. Oleh karena itu, dibutuhkan pula pemahaman dikalangan praktisi hukum bahwa terdapat beberapa akad yang membutuhkan kombinasi, sehingga diharapkan biaya hukum yang timbul dapat disesuaikan. Mingka (2013c) telah memberikan gambaran bahwa pemahaman hybrid contract ini juga harus menyentuh para notaris selaku praktisi hukum yang terkait langsung dalam akad.

Selain memisahkan secara hukum, perlu juga dipahami bahwa substansi wujud pemisahan adalah dengan dasar perhitungan upah (ujrah) yang ditentukan oleh LKS. MUI (2002) dan MUI (2000c) menjelaskan bahwa upah (ujrah) harus didasarkan pada 
Tabel 5. Jurnal untuk Alternatif III

\begin{tabular}{lll}
\hline Memberikan Talangan & \multicolumn{1}{c}{ Menerima ujrah } & \multicolumn{1}{c}{ Pelunasan/Angsuran } \\
\hline (D) Piutang Nasabah & (D) Kas & (D) Kas \\
(K) Kas & (K) Pendapatan Ujrah & (K) Piutang Nasabah \\
\hline
\end{tabular}

pengeluaran riil, bukan pada besaran utang yang diberikan oleh LKS. Implikasi jika LKS menaati ketentuan MUI tersebut, maka besaran ujrah yang didapat oleh LKS tentu saja tidak akan besar. Hal inilah yang menurut penulis menimbulkan resiko kepatuhan terhadap implementasi alternatif III. Alternatif III merupakan bentuk yang paling sederhana dan mudah namun secara ekonomis tidak terlalu menarik bagi LKS.

Alternatif III juga secara substansi apabila dipatuhi dengan seksama akan memberikan dampak pada akuntansi yang diterapkan. Secara substansial, akad yang digunakan hanya qardh dan ijarah, sehingga tidak terlalu rumit. LKS hanya perlu mencatat pada saat: (1) Memberikan talangan, (2) Menerima upah, dan (3) Menerima pelunasan/angsuran utang. Dengan demikian, tidak terdapat implikasi perlakuan terhadap obyek yang dimiliki oleh nasabah. Jurnal yang terjadi dalam transaksi alternatif III tampak pada tabel 5 :

\section{Alternatif Keempat: Kombinasi Akad Qa- rdh dan Ijarah Muntahiya bi Al Tamlik (IMBT)}

\section{ALTERNATIF IV}

1. LKS memberikan qardh kepada nasabah. Dengan qardh tersebut nasabah melunasi kredit (utang)-nya; dan dengan demikian, aset yang dibeli dengan kredit tersebut menjadi milik nasabah secara penuh.

2. Nasabah menjual aset dimaksud angka 1 kepada LKS, dan dengan hasil penjualan itu nasabah melunasi qardh-nya kepada LKS.

3. LKS menyewakan aset yang telah menjadi miliknya tersebut kepada nasabah, dengan akad al-Ijarah al-Muntahiyah bi al-Tamlik.

4. Fatwa DSN Nomor: 19/DSN-MUI/ IV/2001 tentang al-Qardh dan Fatwa DSN Nomor: 27/DSN-MUI/III/2002 tentang al-Ijarah al-Muntahiyah bi al-Tamlik berlaku pula dalam pelaksanaan Pembiayaan Pengalihan Utang sebagaimana dimaksud dalam alternatif IV ini. (MUI 2002)

Alternatif IV dari akad hiwalah yang ditawarkan oleh MUI merupakan model yang paling rumit, sehingga Wiroso (2013) menyatakan bahwa alternatif ini paling sulit di implementasikan. Selain itu, Zaky (2013) juga menilai implikasi akuntansi dari akad ini juga cukup rumit. Alternatif IV merupakan kombinasi dari akad qardh dan IMBT. Adapun akad IMBT itu sendiri merupakan kombinasi dari akad ijarah dan jual beli (ba'i), sebagaimana penjelasan tabel 6:

Berdasarkan tabel tersebut tampak secara jelas tingkat kerumitan dari implemen-

Tabel 6. Akad dan Transaksi dalam Alternatif IV Akad Hiwalah

\begin{tabular}{|c|c|}
\hline Akad & Transaksi \\
\hline 1. Qardh & $\begin{array}{l}\text { 1. LKS memberikan utang kepada nasabah untuk melunasi } \\
\text { utang ke pihak ketiga, sehingga aset menjadi milik nasabah } \\
\text { secara penuh. }\end{array}$ \\
\hline 2. Jual Beli (Ba’i) & 2. Nasabah menjual kepada LKS aset tersebut. \\
\hline $\begin{array}{l}\text { 3. Ijarah Muntahiyah } \\
\text { bit al tamlik (IMBT) }\end{array}$ & $\begin{array}{l}\text { 3. LKS menyewakan kembali menggunakan pola transaksi sewa } \\
\text { (ijarah) diakhir akad menggunakan pilihan: } \\
\text { a. Jual Beli: LKS menjual aset tersebut kepada nasabah. } \\
\text { b. Hibah: LKS menghibahkan aset yang telah disewakan } \\
\text { tersebut kepada nasabah }\end{array}$ \\
\hline
\end{tabular}


Tabel 7. Jurnal untuk Distribusi Qardh Hingga Pembelian Oleh LKS

\begin{tabular}{lll}
\hline Memberikan Talangan & Membeli Aset & Menerima Pelunasan \\
\hline (D)Piutang Nasabah & (D) Aset & (D) Kas \\
(K) Kas & (K) Kas & (K) Piutang Nasabah \\
\hline
\end{tabular}

tasi akad ini. Muawiyah (2008) berpendapat bahwa transaksi jual beli model ini terindikasi mengandung unsur al hielah. Selain itu, terjadi kombinasi akad qardh dan ijarah dalam satu kesatuan akad. Meskipun kedua akad tersebut berdiri sendiri, namun masih dalam satu rangkain transaksi hiwalah dan tidak dapat dipisahkan, bahkan apabila akad ini dipisahkan, maka alternatif IV akan gagal. Kondisi inilah yang mengindikasikan bahwa akad qardh dan ijarah pada alternatif ini merupakan kesatuan.

Alternatif IV juga mengandung transaksi ba'i al inah, yaitu pada transaksi ketika nasabah menjual kepada LKS, kemudian obyek tersebut dijual kembali kepada nasabah melalui mekanisme sewa yang diakhiri dengan perpindahan kepemilikan. Meskipun tidak secara langsung terjadi perpindahan obyek, namun secara substansial transaksi IMBT sebagai bagian dari akad ba'i dan diakhiri dengan perpindahan kepemilikan. Kondisi inilah yang makin membuat alternatif IV ini menjadi semakin sulit diimplementasikan. Risiko kepatuhan dan risiko operasional yang besar menjadikan alternatif ini semakin sulit.

Terlepas dari berbagai permasalahan dalam aspek kepatuhan syariah, implikasi perlakuan akuntansi terhadap alternatif IV ini juga cukup rumit. Mingka (2013c) menekankan sebaiknya proses pencatatan akuntansi untuk hybrid contract mengikuti akad mana yang paling dominan. Namun demikian, secara akuntansi terdapat transaksi yang sudah layak untuk dilakukan pencatatan. Kompleksitas perlakuan akuntansi pada alternatif IV juga ditimbulkan dari berbagai akad yang terjadi. Alternatif perlakuan akuntansi pada saat proses distribusi qardh hingga perpindahan kepemilikan tampak pada tabel 7 :

Setelah obyek telah menjadi milik LKS, proses selanjutnya adalah LKS melakukan akad IMBT, sehingga tampak pada jurnal berikut:

Keseluruhan rangkaian jurnal ini pada dasarnya merupakan satu kesatuan dari akad hiwalah alternatif IV, dan hanya akan tampak pada LKS yang melakukan pencatatan pada setiap tahapan transaksi.

\section{SIMPULAN}

Berdasarkan alternatif yang ditawarkan dalam fatwa DSN MUI No. 31 Tahun 2002 tersebut, setidaknya terdapat penggabungan akad dalam setiap alternatifnya, antara lain: (1) Alternatif I memberikan alternatif gabungan akad qardh dengan murabahah. (2) Alternatif II memberikan alternatif gabungan akad syirkah al milk dengan murabahah. (3) Alternatif III memberikan alternatif gabungan akad qardh dengan ijarah. (4) Alternatif IV memberikan alternatif gabungan akad qardh dengan ijarah muntahiyah bit tamlik.

Tabel 8. Jurnal untuk Proses IMBT

\begin{tabular}{lll}
\hline Mereklasifikasi Aset Ijarah & \multicolumn{1}{c}{ Menerima Ujrah } & \multicolumn{1}{c}{ Perpindahan Aset } \\
\hline (D) Aset Ijarah & (D) Kas & Mekanisme Hibah \\
(K) Aset & (K) Pendapatan Ujrah & (D) Akm. Penyu. Aset \\
& & (K) Aset Ijarah \\
& Mekanisme Jual (untung) \\
& (D) Akm. Penyu. Aset \\
& (D) Kas \\
& (K) Aset Ijarah \\
& (K) Keuntungan \\
& Mekanisme Jual (rugi) \\
& (D) Akm. Penyu. Aset \\
& (D) Kas \\
& (D) Kerugian \\
& (K) Aset Ijarah \\
&
\end{tabular}


Hasil analisis penelitian ini menunjukkan bahwa masing-masing alternatif menghadapi kendala pada ketidaksesuaian dengan prinsip dan karakteristik transaksi syariah, meskipun hal ini telah difatwakan oleh DSN MUI. Selain itu, masing-masing alternatif yang ditawarkan memiliki implikasi perlakuan akuntansi yang relatif kompleks.

Beberapa pendapat yang menyarankan agar perlakuan akuntansi hanya didasarkan pada akad yang paling dominan, ternyata memiliki kendala secara substantif jika diimplementasikan. Oleh karena itu, peneliti tetap memberikan masukan berupa alternatif jurnal untuk setiap alternatif yang ditawarkan DSN. Meskipun peneliti menyadari kompleksitas perlakuan akuntansi menjadi semakin nampak secara nyata. Namun demikian, hal ini lebih tepat jika dibenturkan dengan keniscayaan untuk melakukan pencatatan pada setiap transaksi yang berimplikasi pada nilai ekonomis. Hal ini terbukti dengan adanya beberapa pernyataan pada tataran praktis yang menyatakan bahwa beberapa alternatif sangat sulit untuk diterapkan.

Penelitian ini didasarkan pada studi literatur, sehingga masih memiliki beberapa keterbatasan terutama dalam aspek perkembangan data maupun informasi. Selain itu, penelitian ini terkendala pada belum adanya standar akuntansi yang secara khusus mengatur tentang akad hiwalah. Oleh karena itu, peneliti memberikan beberapa saran, diantaranya: (a) Bagi peneliti selanjutnya, agar mengembangkan metode penelitian yang lebih mendekatkan pada kondisi empiris dalam transaksi pembiayaan take over (hiwalah). (b) Bagi regulator, terutama dewan standar akuntansi syariah, untuk tetap lebih menekankan substansi transaksi sebagai dasar menerbitkan suatu standar, namun tetap mempertimbangkan keberadaan hybrid contract dalam tataran praktis. (3) Bagi praktisi LKS, agar lebih memperhatikan substansi akad dan transaksi daripada bentuk akad yang disepakati, sehingga karakteristik utama transaksi syariah senantiasa terjaga serta bebas dari upaya tipu daya (al hielah) terhadap kepatuhan syariah.

\section{DAFTAR RUJUKAN}

Ad Duwaisy, Ahmad bin Abdurrazzaq. 2009. Fatwa-Fatwa Jual Beli Oleh Ulama Besar Terkemuka. Pustaka Imam Syafi'i. Bogor.

Antonio, Muhammad Syafii. 2001. Bank Syariah: Dari Teori Ke Praktik. Gema Insani. Jakarta.

Ayub, Muhammad. 2007. Understanding Islamic Finance. John Willey \& Sons. England.

Badri, Muhammad Arifin. 2010. Sifat Perniagaan Nabi: Panduan Praktis Fiqih Perniagaan Islam. Pustaka Darul Ilmi. Bogor.

Badri, Muhammad Arifin. 2009. Mencari Solusi Perbankan Syariah. www.pengusahamuslim.com (diakses tanggal 5 Januari 2011).

Badri, Muhammad Arifin. 2009. Prinsip Jual Beli dalam Ajaran Islam. www.pengusahamuslim.com (diakses tanggal 5 Januari 2011).

Badri, Muhammad Arifin. 2009. Riba \& Tinjauan Kritis Perbankan Syari'ah. Pustaka Darul Ilmi. Bogor.

Badri, Muhammad Arifin. 2009. Riba dan Tinjauan Kritis Perbankan Syariah. Disampaikan dalam Kegiatan Bedah Buku di Masjid Pondok Indah Jakarta, tanggal 21 Mei 2009. www.kajian.net (diakses pada tanggal 2 Januri 2011).

Bank Indonesia. 2011a. Outlook Perbankan Syariah 2011. www.bi.go.id (diakses pada tanggal 10 September 2011).

Bank Indonesia. 2011b. Program Akselerasi Perbankan Syariah. www.bi.go.id (diakses pada tanggal 6 Juni 2011).

Bank Indonesia. 2011c. Sekilas Perbankan Syariah di Indonesia. www.bi.go.id (diakses pada tanggal 10 September 2011).

Bank Indonesia. 2013. Statistik Perbankan Syariah. www.bi.go.id (diakses pada tanggal 6 April 2013).

Eferin, Sujoko, Stevanus Hadi Darmadji, dan Yuliawati Tan. 2004. Metode Penelitian untuk Akuntansi: Sebuah Pendekatan Praktis. Bayu Media. Malang.

Gumilar. 2008. Social Exchange Theory John Thibaut \& Harold Kelley, http://gumilarcenter.com/Makalah/SocialExchangeTheory.pdf (diakses pada tanggal 29 Januari 2008).

Hasan, M. Iqbal. 2002. Pokok-pokok Materi Metodologi Penelitian dan Aplikasinya. Ghalia Indonesia. 
Hayati, Mardhiyah. 2008. Telaah Terhadap Fatwa DSN NO: 31/DSN-MUI/VI/2002. http//msi-uii.net (diakses pada tanggal 1 Juni 2013).

IAI. 2009. Standar Akuntansi Keuangan per 1 Juli 2009: Kerangka Dasar Penyusunan dan Pelaporan Keuangan Syariah. Salemba Empat. Jakarta.

Indriantoro, Nur dan Bambang Supomo. 2002. Metodologi Penelitian Bisnis untuk Akuntansi dan Manajemen. BPFE. Yogyakarta.

Karim, Adiwarman A. 2010. Bank Islam: Analisis Fiqih dan Keuangan Edisi 4. Raja Grafindo Persada. Jakarta.

Karim, Adiwarman A. 2005. Klub Bisnis Syariah: Pembiayaan Take Over. Gontor Magazine Edisi 06 Tahun III Oktober 2005.

Mingka, Agustianto. 2013a. 10 Alasan Mengapa Teori dan Praktik Hybrid Contracts Perlu Dipahami dalam Mengembangkan Perbankan dan Keuangan Syariah. www.agustiantocentre.com (diakses pada tanggal 1 Juni 2013).

Mingka, Agustianto. 2013b. Hybrid Contract dalam Keuangan Syariah. www.agustiantocentre.com (diakses pada tanggal 1 Juni 2013).

Mingka, Agustianto. 2013c. 10 Alasan Mengapa Teori dan Praktik Hybrid Contracts Perlu Dipahami dalam Mengembangkan Perbankan dan Keuangan Syariah. www.agustiantocentre.com (diakses pada tanggal 25 November 2013).

Muawiah. 2008. Jual Beli Dengan Cara Al Inah. www.al-atsariyyah.com (diakses pada tanggal 25 November 2013).

MUI. 2000a. Fatwa Dewan Syariah Nasional MUI NO: 04/DSN-MUI/IV/2000 Tentang Murabahah. DSN MUI. Jakarta.

MUI. 2000b. Fatwa Dewan Syariah Nasional MUI NO: 08/DSN-MUI/IV/2000 Tentang Pembiayaan Musyarakah. DSN MUI. Jakarta.

MUI. 2000c. Fatwa Dewan Syariah Nasional MUI NO: 09/DSN-MUI/IV/2000 Tentang Pembiayaan Ijarah. DSN MUI. Jakarta.

MUI. 2000d. Fatwa Dewan Syariah Nasional MUI NO: 12/DSN-MUI/IV/2000 Tentang Hawalah. DSN MUI. Jakarta.

MUI. 2000e. Fatwa Dewan Syariah Nasional MUI NO: 15/DSN-MUI/IX/2000 Tentang Prinsip Distribusi Bagi Hasil. DSN MUI. Jakarta.
MUI. 2001. Fatwa Dewan Syariah Nasional MUI NO: 19/DSN-MUI/IV/2001 Tentang Al Qardh. DSN MUI. Jakarta.

MUI. 2002. Fatwa Dewan Syariah Nasional MUI NO: 27/DSN-MUI/III/2002 Tentang Al-Ijarah Al-Muntahiyah Bi Al-Tamlik. DSN MUI. Jakarta.

MUI. 2002. Fatwa Dewan Syariah Nasional MUI NO: 31/DSN-MUI/VI/2002 Tentang Pengalihan Utang. DSN MUI. Jakarta.

Munandar, Aris. 2011. Pengertian Jual Beli. www.pengusahamuslim.com (diakses pada tanggal 5 Januari 2011).

Mustofa, Hasan. 2010. Perspektif Dalam Psikologi Sosial. http://andinia-psikelompok.blogspot.com (diakses pada tanggal 30 Oktober 2010).

Muttaqin, Husnul. 2010. Teori Pertukaran Teori Sosiologi Modern. http://sosiologiprofetik.wordpress.com (diakses pada tanggal 30 Desember 2010).

Nurhayati, Sri; Wasilah. 2013. Akuntansi Syariah di Indonesia Edisi 3. Salemba Empat. Jakarta.

Sabatelli, Ronald M. 2010. Social Exchange Theory - Major Contemporary Concepts, http://family.jrank.org/ (diakses pada tanggal 20 Desember 2010).

Sugiyono. 2005. Memahami Penelitian Kualitatif. CV Alfabeta. Bandung.

Tarmizi, Erwandi. 2012. Gadai Emas Syariah, Kamuflase Riba'. Majalah Pengusaha Muslim Edisi 24 Tahun 2012. Yayasan Bina Pengusaha Muslim. Yogyakarta

Wiroso, 2011a. Akuntansi Transaksi Syariah. Ikatan Akuntan Indonesia. Jakarta.

Wiroso. 2011b. "Pengantar Akuntansi dan Laporan Keuangan Bank Syriah". Disampaikan dalam acara TOT Akuntansi Perbankan Syariah di Universitas Padjajaran Bandung 28-30 Maret 2011.

Yaya, Rizal, Aji Erlangga Martawireja, Ahim Abdurrahim. 2009. Akuntansi Perbankan Syariah Teori dan Praktik Kontemporer. Salemba Empat. Jakarta.

Yin, Robert. K. 2002. Studi Kasus: Desain dan Metode. Raja Grafindo Persada. Jakarta.

Zaid, Bakr Abu. 2009. Hukum Murabahah Baitul Mal wa Tamwil (BMT). http:// wahonot.wordpress.com (diakses pada tanggal 7 September 2009).

Zaky, Achmad. 2013. Modul Pelatihan Akuntansi dan Keuangan Syariah: Akad dan Transaksi Syariah Edisi 2. Islamic Finance and Accounting Studies (IFAS) JAFEB UB. Malang. 